\author{
RAFAŁ STANKIEWICZ \\ ORCID: 0000-0002-3227-7771 \\ Uniwersytet Warszawski
}

\title{
O ISTOCIE ZAWODU RADCY PRAWNEGO
}

\begin{abstract}
Abstrakt: Przedmiotem artykułu są rozważania poświęcone szczególnym cechom, jakie powinien mieć profesjonalny pełnomocnik prawny. Istnienie zawodu radcy prawnego jako zawodu zaufania publicznego oraz ukształtowane w toku jego wykonywania ideały i obowiązki etyczne są jedną z gwarancji realizowania zawartej w Konstytucji RP zasady demokratycznego państwa prawnego. Radcy prawni współuczestniczą w procesie rozstrzygania o realizacji interesu publicznego oraz zabezpieczeniu praw podmiotowych obywateli, przedsiębiorców i innych jednostek organizacyjnych. Istotą funkcjonowania tych samorządów staje się więc działanie na rzecz dobra wspólnego w zakresie, w jakim może ona wspierać, a przede wszystkim uzupełniać wykonywanie zadań przez organy władzy publicznej. Każdego radcę prawnego powinna cechować niezależność. Wyznacznikami niezależności staje się profesjonalizm, godność wykonywania zawodu, nieskazitelność charakteru oraz odwaga w wykonywaniu czynności zawodowych.
\end{abstract}

Słowa kluczowe: radca prawny, zawód zaufania publicznego, profesjonalizm, godność

\section{ZAGADNIENIA WSTĘPNE}

Dążenie do wypełnienia sprawiedliwości jest możliwe również dzięki zagwarantowaniu mocnych podstaw wykonywania zawodu przez profesjonalnych pełnomocników prawnych — radców prawnych i adwokatów. Ich udział we wspieraniu wielu podmiotów uczestniczących $\mathrm{w}$ obrocie prawnym jest dzisiaj pewnym standardem, gwarantowanym regulacjami procesowymi. Przedmiotem artykułu będą jednak rozważania poświęcone wyłącznie istocie zawodu radcy prawnego. Szczegółowe uregulowania dotyczące wykonywania zawodu zaufania publicznego radcy prawnego zostały określone w ustawie z dnia 6 lipca 1982 roku o radcach prawnych (dalej: u.r.p.) $)^{1}$. Zgodnie $\mathrm{z}$ art. 2 tejże ustawy pomoc prawna świadczona przez radcę prawnego ma na celu ochronę prawną interesów podmiotów, na których rzecz jest wykonywana ${ }^{2}$. Nie ma wątpliwości, że wykonywanie zawodu

1 Tekst jedn. Dz.U. z 2020 r. poz. 75.

2 Por. więcej B. Sołtys, Komentarz do art. 2, [w:] Ustawa o radcach prawnych. Komentarz, red. T. Scheffler, Warszawa 2018, s. 59 n. 
radcy prawnego, polegające na świadczeniu pomocy prawnej i mające na celu ochronę prawną interesów podmiotów, na których rzecz jest wykonywana, bezpośrednio wiąże się z ochroną interesu publicznego. Dotyczy to zarówno aktywności zawodowej radców prawnych świadczących pomoc prawną na rzecz podmiotów władzy publicznej, jak i odnosi się do świadczenia pomocy prawnej na rzecz podmiotów - przedsiębiorców sektora prywatnego i osób fizycznych. W każdym z tych obszarów wskazać można na zaangażowanie radców prawnych w realizację interesu publicznego.

Radcy prawni współuczestniczą w procesie rozstrzygania o realizacji interesu publicznego oraz zabezpieczeniu praw podmiotowych obywateli, przedsiębiorców i innych jednostek organizacyjnych. Istotą funkcjonowania tych samorządów staje się więc działanie na rzecz dobra wspólnego w zakresie, w jakim może ona wspierać, a przede wszystkim uzupełniać wykonywanie zadań przez organy władzy publicznej. Radcy prawni, oprócz państwowych organów ochrony prawnej, stoją na straży przestrzegania wolności i praw obywatelskich. Jako grupa zawodowa są oni profesjonalnie przygotowani do ochrony praw podmiotowych obywateli, świadcząc im pomoc prawną w trakcie przygotowania do procesów sądowych i we wszelkich dostępnych alternatywnych metodach rozwiązywania sporów.

Szczególna rola przypada radcom prawnym jako profesjonalnym pełnomocnikom procesowym $\mathrm{w}$ toku postępowań sądowych ${ }^{3}$ - dotyczy to zwłaszcza ich udziału w realizacji instytucji tak zwanego przymusu adwokacko-radcowskiego ${ }^{4}$. $\mathrm{Z}$ perspektywy wpływu radcy prawnego na standard prowadzonego postępowania sądowego (ujmowanego jako element zapewnienia jednostce prawa do sądu) istotne znaczenie ma kontradyktoryjność postępowania wzbogacona o regułę równości broni. Ta ostatnia nakazuje umożliwienie każdej ze stron procesu takie przedstawienie sprawy, które nie postawi jej w jawnie niekorzystnej sytuacji w porównaniu ze stroną przeciwną. Zasada równości broni oznacza zapewnienie stronie procesu sądowego zapoznania się ze wszystkimi przedstawionymi dowodami i złożonymi wyjaśnieniami oraz wypowiedzenia się co do tych dowodów i twierdzeń w celu wywarcia wpływu na orzeczenie sądu. W konsekwencji udział profesjonalnego pełnomocnika procesowego wzmacnia pozycję strony, pozwala jej bowiem na umiejętne i efektywne wykorzystanie wszystkich dostępnych stro-

3 W procedurze karnej, cywilnej i sądowoadministracyjnej.

${ }^{4}$ Instytucja ta, występująca w każdej z procedur sądowych, oznacza obowiązek zastąpienia strony przez profesjonalnego pełnomocnika przy dokonywaniu określonej czynności procesowej albo w określonej fazie postępowania. Wskazać można chociażby na postępowanie cywilne, w którym stosowanie tejże instytucji dotyczy całego postępowania przed Sądem Najwyższym, oraz na czynności procesowe związane z postępowaniem przed tym sądem podejmowane przed sądem niższej instancji (art. $87^{1} \S 1$ k.p.c.). W postępowaniu karnym przymus adwokacko-radcowski występuje w kilku rodzajach postępowań (między innymi przy składaniu kasacji — art. 562 § k.p.k. czy też wniosku o wznowienie postępowania — art. 545 § 2 k.p.k.). W postępowaniu sądowoadministracyjnym przymus adwokacko-radcowski występuje między innymi przy wnoszeniu skargi kasacyjnej (art. 175 § 1 p.p.s.a.), czy też skargi do NSA o wznowienie postępowania (art. 276 p.p.s.a.). 
nie środków procesowych. Znaczenie właściwego zachowania profesjonalnego pełnomocnika procesowego jest tym istotniejsze, że strona, która wskutek własnych zachowań pozbawiła się możności udowodnienia dochodzonych roszczeń, nie może racjonalnie utrzymywać, że została pozbawiona prawa do sprawiedliwego i rzetelnego procesu.

Radcom prawnym powierzono też świadczenie pomocy prawnej na rzecz podmiotów władzy publicznej. Profesjonalizm zawodowy wyrażający się w odpowiedniej wiedzy i doświadczeniu pozwala na gruntowne wsparcie prawne organów stanowiących i stosujących prawo wszędzie tam, gdzie ich aktywność realizuje interes publiczny. Bez profesjonalnej pomocy prawnej podmioty te nie mogłyby realizować zadań, do których zostały przeznaczone regulacjami o charakterze ustrojowym.

Zawód radcy prawnego może wykonywać osoba spełniająca wymagania określone ustawowo, a czynić to powinna ze starannością wynikającą z wiedzy prawniczej oraz zasad etyki radcowskiej (art. 3 ust. 1 i 2 u.r.p.). W celu zapewnienia wysokich kwalifikacji merytorycznych osób wykonujących zawód radcy prawnego ustawodawca przewidział złożony system uzyskiwania uprawnień zawodowych oraz surowe wymogi stawiane kandydatom do zawodu (art. 24 u.r.p.). Przegląd postanowień Kodeksu etyki radcy prawnego ${ }^{5}$ potwierdza cechy jakościowe osób wykonujących ten zawód. W preambule znajdujemy znamienne stwierdzenie:

Radca prawny wykonujący w sposób samodzielny i niezależny wolny zawód służy interesom wymiaru sprawiedliwości, jak również tym, których prawa i wolności zostały mu powierzone w celu ochrony. Zawód radcy prawnego podlegający ochronie Konstytucji Rzeczypospolitej Polskiej stanowi jedną z gwarancji poszanowania prawa. Jest to zawód zaufania publicznego respektujący ideały i obowiązki etyczne ukształtowane w toku jego wykonywania.

Zawód radcy prawnego jako zawód zaufania publicznego oraz ukształtowane w toku jego wykonywania ideały i obowiązki etyczne są jedną z gwarancji realizowania zawartej w Konstytucji $\mathrm{RP}^{6}$ zasady demokratycznego państwa prawnego. Samo zaś wykonywanie zawodu nakłada na radcę prawnego obowiązki o charakterze prawnym i etycznym nie tylko wobec klienta, sądów i innych organów, lecz także wobec społeczeństwa jako takiego. Zdanie to wyraża publiczny charakter zawodu radcy prawnego co najmniej w tym sensie, że istnienie tego zawodu oraz jego wykonywanie przez osoby mające określone cechy jakościowe samo w sobie jest ważnym interesem publicznym.

Niewątpliwie świadczenie przez radców prawnych pomocy prawnej wiąże się z przestrzeganiem praw i wolności obywatelskich (art. 30, art. 31 ust. 1 i 2, art. 32 ust. 1 i 2, 45 ust. 1 Konstytucji RP). Mają oni nie tylko prawo, lecz także

5 Zob. Kodeks etyki radcy prawnego, załącznik do uchwały nr 3/2014 Nadzwyczajnego Krajowego Zjazdu Radców Prawnych z dnia 22 listopada 2014 roku (dalej: KERP).

${ }^{6}$ Konstytucja Rzeczypospolitej Polskiej z dnia 2 kwietnia 1997 roku, Dz.U. Nr 78, poz. 483 ze zm. 
— a może przede wszystkim — obowiązek wspierać organy ochrony prawnej W realizacji tychże praw i wolności obywatelskich. W żaden sposób nie będzie przesadą stwierdzenie, że bez istnienia zawodu radcy prawnego (oraz zawodu adwokata) niemożliwe byłoby zapewnienie realizacji założeń przyjętych w art. 45 ust. 1 Konstytucji RP. Przepis ten stanowi, że każdy ma prawo do sprawiedliwego i jawnego rozpoznania sprawy bez nieuzasadnionej zwłoki przez właściwy, niezależny, bezstronny i niezawisły sąd ${ }^{7}$.

Wskazać należy, że dzięki rzetelności, wiedzy i etycznemu uwrażliwieniu na powierzane w tajemnicy przez klientów informacje i opiekę nad ich prawami podmiotowymi radcy prawni przyczyniają się do realizacji rządów prawa. Ich powinności i obowiązki ochrony praw podmiotowych wszystkich potrzebujących są tym większe, im większe zagrożenia stoją przed niezależnością sądów i niezawisłością sędziowską.

Jedną z podstawowych wartości zawodu radcy prawnego jest jego niezależność. Artykuł 7 KERP stanowi, że niezależność radcy prawnego oznacza, iż musi on być wolny od wszelkich wpływów, a szczególnie tych, które mogą wynikać z jego osobistych interesów czy nacisków zewnętrznych, ograniczeń, gróźb ingerencji bezpośredniej lub pośredniej z jakiejkolwiek strony lub z jakiegokolwiek powodu. Od radcy prawnego wymaga się nieulegania wpływom — zwłaszcza tym, które mogą wyniknąć z jego osobistych interesów lub nacisków z zewnątrz. Radca prawny powinien unikać wszelkich ograniczeń własnej niezależności i nie może odstępować od zasad etyki w celu spełnienia oczekiwań klienta, sądu lub osób trzecich (art. 11 ust. 3 KERP).

\section{ZAWÓD RADCY PRAWNEGO - ZAWÓD ZAUFANIA PUBLICZNEGO}

Zawód radcy prawnego należy do grupy „zawodów zaufania publicznego”, których wykonywanie wiąże się z koniecznością legitymowania się specjalistyczną wiedzą potwierdzoną zdanym egzaminem państwowym bądź w ustawowym trybie uzyskaniem uprawnienia do wykonywania zawodu. Chodzi tutaj zawody, których uprawianie związane jest z kontraktem społecznym wynikającym ze szczególnej roli profesjonalistów określonego zawodu w społeczeństwie.

Mimo że ustawodawca nie stworzył legalnej definicji pojęcia „zawód zaufania publicznego", odpowiedzi na pytanie, kiedy mamy do czynienia z zawodem zaufania publicznego, należy szukać w dość bogatym dorobku doktryny i orzecz-

7 Więcej między innymi na temat konstytucyjnego prawa do sądu zob. A. Wróbel, Prawo do sądu, [w:] Konstytucja RP w praktyce. Konferencja naukowa, Warszawa 1999, s. 212; M. Kłopocka, Prawo do sądu w orzecznictwie Trybunału Konstytucyjnego, „Przegląd Prawa i Administracji” 76, 2008, s. 63; Z. Czeszejko-Sochacki, Prawo do sądu w świetle Konstytucji Rzeczypospolitej Polskiej (ogólna charakterystyka), „Państwo i Prawo” 1997, nr 11-12, s. 88. 
nictwa. W literaturze przedmiotu najczęściej wskazywane się następujące cechy zawodów zaufania publicznego: a) szczególna doniosłość prawidłowego i zgodnego $\mathrm{z}$ interesem publicznym wykonywania - istotnego z racji znaczenia, jaką dana dziedzina społecznej aktywności zawodowej odgrywa w społeczeństwie oraz z racji konieczności zapewnienia ochrony gwarantowanych konstytucją praw podmiotowych jednostki; b) powierzanie w warunkach wysokiego zaufania uprawiającym taki zawód informacji osobistych i dotyczących życia prywatnego osób korzystających z ich usług; c) uznawanie tych informacji za tajemnicę zawodową, która nie może być ujawniona; d) objęcie osób dysponujących taką tajemnicą w wypadku możliwości naruszenia istotnych dóbr jednostki w razie jej ujawnienia — immunitetem zwalniającym je od odpowiedzialności karnej za nieujawnienie informacji; e) korzystanie ze świadczeń tych zawodów często w razie nastąpienia realnego albo choćby potencjalnego niebezpieczeństwa dla dóbr jednostki o szczególnym charakterze (na przykład życie, zdrowie, wolność, godność, dobre imię); f) niepodleganie regułom hierarchii urzędniczej; g) występowanie sformalizowanej deontologii zawodowej oraz rękojmia należytego i zgodnego z interesem publicznym wykonywania zawodu, gwarantowana z jednej strony znacznymi obostrzeniami w kwestii dostępu do wykonywania każdego z zawodów zaufania publicznego, obejmującymi nie tylko konieczność ukończenia odpowiedniego szkolenia, lecz także cechowanie się odpowiednim poziomem etycznym, z drugiej — sprawowaną w interesie publicznym pieczą organów samorządu zawodowego ${ }^{8}$.

W wyroku z dnia 1 grudnia 2009 roku Trybunał Konstytucyjny nadto zauważył, że zawód zaufania publicznego ,polega na obsłudze osobistych potrzeb ludzkich, wiążący się z przyjmowaniem informacji dotyczących życia osobistego i zorganizowany $\mathrm{w}$ sposób uzasadniający przekonanie społeczne o właściwym dla interesów jednostki wykorzystywaniu tych informacji przez świadczących usługi"9. Wykonywanie zawodu zaufania publicznego określane jest dodatkowo normami etyki zawodowej, szczególną treścią ślubowania, tradycją korporacji zawodowej czy szczególnym charakterem wykształcenia wyższego i uzyskanej specjalizacji (aplikacja) ${ }^{10}$. „Zawód zaufania publicznego” jest więc zawodem polegającym na obsłudze osobistych potrzeb ludzkich, wiążącym się z przyjmowaniem informacji dotyczących życia osobistego i zorganizowanym w sposób uzasadnia-

8 Zob. P. Sarnecki, Komentarz do art. 17 konstytucji, [w:] Konstytucja Rzeczypospolitej Polskiej. Komentarz, t. 4, red. L. Garlicki, Warszawa 1999-2007; idem, Opinia w sprawie wyktadni art. 17 ust. 1 Konstytucji Rzeczypospolitej Polskiej, „Przegląd Sejmowy” 2001, nr 2, s. 75-76; M. Tabernacka, Pojęcie zawodu zaufania publicznego, „Przegląd Prawa i Administracji” 62, 2004, s. 302.

9 Zob. wyrok Trybunału Konstytucyjnego z dnia 1 grudnia 2009 roku, sygn. akt K 4/08, Dz.U. Nr 2010, poz. 1628.

${ }^{10}$ Wyrok Trybunału Konstytucyjnego z dnia 26 listopada 2003 roku, SK 22/02; więcej zob. P. Sarnecki, Pojęcie zawodu zaufania publicznego (art. 17 ust. 1 Konstytucji na przykładzie adwokatury), [w:] Konstytucja. Wybory. Parlament. Studia ofiarowane Zdzistawowi Jaroszowi, red. L. Garlicki, Warszawa 2000, s. 155 n. 
jący przekonanie społeczne o właściwym interesom jednostki wykorzystywaniu tych informacji przez świadczących usługi. Wykonywanie zawodu zaufania publicznego określane jest dodatkowo normami etyki zawodowej, szczególną treścią ślubowania, tradycją korporacji zawodowej czy szczególnym charakterem wykształcenia wyższego i uzyskanej specjalizacji (aplikacja). Mówiąc więc o cechach wyróżniających zawód zaufania publicznego, jakim jest zawód radcy prawnego, należy ponownie podkreślić wysoki poziom wiedzy i umiejętności osób wykonujących te zawody, związanie normami etycznymi, w tym obowiązkiem przestrzegania tajemnicy zawodowej, podleganie obowiązkowi szkolenia zawodowego, szczególną więź między radcą prawnym czy adwokatem a osobą, na której rzecz świadczą pomoc prawną opartą na zaufaniu, jak również niezależność i samodzielność w wykonywaniu zawodu. Obserwowany ciągły wzrost zaufania do pomocy prawnej świadczonej przez radców prawnych oraz coraz liczniejsze ich grono z pewnością przyczynia się do realizacji takich wartości jak praworządność i sprawiedliwość oraz do ochrony wolności i praw obywatelskich. Wywiera też coraz większy wpływ na wzrost świadomości prawnej obywateli, co ma istotne znaczenie w procesie kształtowania się społeczeństwa obywatelskiego.

\section{NIEZALEŻNOŚĆ RADCY PRAWNEGO}

Jak wskazano na początku, immanentnym celem funkcjonowania w społeczeństwie radców prawnych jako profesjonalnych pełnomocników prawnych jest świadczenie pomocy prawnej opartej na przymiocie niezależności. Problemem podstawowym jest jednak to, w jaki sposób rozumiemy tę niezależność. Należy podjąć próbę zdefiniowania pojęcia niezależności (radcy prawnego), poczynając od jego potocznego znaczenia. Pojęcie „niezależność” w ujęciu słownikowym traktowane jest wielorako. W internetowym Stowniku języka polskiego $P W N$ „,niezależny" to między innymi:

1. niepodporządkowany komuś, czemuś, decydujący o sobie; też: świadczący o braku podporządkowania komuś lub czemuś; 2. niebędący wyznaczonym, zdeterminowanym przez coś; 3 . wygłaszający bezstronne opinie, niekierujący się interesem żadnej grupy społecznej ${ }^{11}$.

Każdy z zaprezentowanych tu wymiarów pojęcia „niezależny” może odnosić się do atrybutów przypisywanych radcy prawnemu. W tym kontekście pojęcie „niezależności” może być rozumiane jako wolne od wszelkich nacisków, wpływów, przesądów zachowanie profesjonalnego pełnomocnika prawnego — radcy prawnego. Nie ma wątpliwości, że niezależność radcy prawnego należy do fundamentalnych cech jego statusu. Regulacje prawne odnoszące się do osób wykonujących zawód radcy prawnego czy adwokata wskazują niezbicie, że osoby te ce-

11 https://sjp.pwn.pl/slowniki/niezale $\%$ C5\%BCno\%C5\%9B $\%$ C4\%87.html. 
chują się niewątpliwie wysokimi kwalifikacjami merytorycznymi oraz wysokimi kwalifikacjami etycznymi, pośród których na szczególną uwagę zasługuje właśnie niezależność. Istota zawodu radcy prawnego, powiązana z jego niezależnością, tkwi w kilku wymiarach. Należą do nich: profesjonalizm, godność zawodowa, nieskazitelność charakteru, odwaga w wykonywaniu obowiązków zawodowych.

$\mathrm{Z}$ działalnością radcy prawnego $\mathrm{w}$ obszarze wymiaru sprawiedliwości atrybut niezależności wiąże się z niemożliwością podlegania zewnętrznym naciskom w związku ze świadczeniem pomocy prawnej. Niezależność oznacza obiektywne korzystanie przez radcę prawnego z własnej wiedzy i doświadczenia niepowiązanej w żaden sposób zależnością od klienta lub jakichkolwiek innych czynników zewnętrznych. Niezależność to samodzielne podejmowanie decyzji, niepodyktowane naciskami w trakcie podejmowania jakichkolwiek czynności w zakresie świadczenia pomocy prawnej.

\subsection{PROFESJONALIZM RADCY PRAWNEGO}

Niezależność to przede wszystkim profesjonalizm pełnomocnika. Zawodom społecznie kwalifikowanym jako tak zwane zawody zaufania publicznego społeczeństwo stawia wymóg bardzo wysokich kwalifikacji fachowych, stałego doskonalenia umiejętności i zasobu wiedzy fachowej, a także bardzo wysokich, wyższych niż przeciętnie zasad etycznych, nienarzucanych z zewnątrz, natomiast tradycyjnie kształtowanych przez samo środowisko korporacji zawodowej ${ }^{12}$. Profesjonalizm w zawodzie radcy prawnego oznacza, że radca prawny nie tylko musi mieć głęboką teoretyczną wiedzę prawniczą, ale także musi umieć ją stosować w praktyce. Tym samym, „niezależny” radca prawny to osoba doskonale przygotowana merytorycznie do podejmowania obsługi prawnej.

Do kwestii wysokiego poziomu merytorycznego osób wykonujących zawód radcy prawnego odnosi się art. $23 \mathrm{KERP}$, który wymaga od radcy prawnego dbałości o rozwój zawodowy poprzez kształcenie ustawiczne. Dlatego też radca prawny obowiązany jest brać udział w szkoleniach zawodowych i w danym okresie rozliczeniowym zdobyć określoną liczbę punktów szkoleniowych.

Profesjonalizm to nie tylko wiedza i doświadczenie, ale również obowiązek takiego działania, które będzie powiązane z przestrzeganiem tajemnicy zawodowej. Naruszanie tajemnicy zawodowej pozostaje bowiem w sprzeczności z istotą i charakterem relacji wynikających z pełnomocnictwa procesowego (narusza zaufanie do pełnomocnika, któremu powierza się swoje sprawy). Tajemnica zawodowa to niezwykle istotny czynnik, zapewniający prawidłowość świadczenia pomocy prawnej i pozwalający na zbudowanie szczególnej więzi z klientem. Służy ona nie tylko osobom korzystającym z pomocy przedstawicieli zawodów prawniczych, ale jest elementem prawidłowego funkcjonowania wymiaru sprawiedli-

12 P. Sarnecki, Radca prawny..., s. 34 n. 
wości i całego systemu ochrony prawnej w demokratycznym państwie. Tajemnica zawodowa jest obowiązkiem radcy prawnego, a jej przestrzeganie umożliwia zbudowanie relacji opartej na zaufaniu. Obowiązku zachowania tajemnicy zawodowej, umieszczonego w art. 3 u.p.r., nie można oddzielać od celu, dla którego istnieje zawód radcy prawnego. Cel ten z kolei określony został w cytowanym już art. 2 ustawy. Pamiętać należy bowiem, że klienci radców prawnych, szukający pomocy prawnej i ochrony swoich interesów, powierzają im istotne informacje z niemal każdej sfery swojego życia osobistego czy zawodowego i mają prawo oczekiwać, by były one należycie chronione przed dostępem osób trzecich. Regulacje dotyczące obowiązku zachowania tajemnicy zawodowej znajdują się zarówno w ustawach regulujących wykonywanie zawodu radcy prawnego i adwokata, jak i w kodeksach etycznych uchwalonych przez oba samorządy.

\subsection{GODNOŚĆ ZAWODOWA}

Z pojęciem niezależności w wykonywaniu zawodu radcy prawnego wiąże się problem godności zawodowej. Pisał o tym T. Scheffler:

godność zawodu radcy prawnego jest to przekonanie, że pewna określona działalność zarobkowa polegająca na świadczeniu pomocy prawnej na zasadach i w granicach ustalonych przez państwo oraz w ramach prawnie wyodrębnionej grupy cieszącej się zdaniem ustawodawcy walorem zaufania publicznego odgrywa z samej swej istoty tak kluczową rolę w stabilizowaniu porządku społecznego, że cieszy się w związku z tym szczególnym prestiżem i zaufaniem społecznym oraz oczekiwaniem społecznym zakładającym wysoki standard wykonywanych czynności zarobkowych zarówno w aspekcie prakseologicznym, jak i w zakresie relacji personalnych wobec klientów i innych podmiotów uczestniczących w tych czynnościach. To wyobrażenie społeczne o zawodzie generuje następnie oczekiwania i wyobrażenia ludzkie dotyczące poszczególnych osób wykonujących ów zawód, a także kształtuje wzorce i schematy zachowań zawodowych dla osób wykonujących tenże zawód ${ }^{13}$.

\subsection{NIESKAZITELNOŚĆ CHARAKTERU}

Trzecia cecha determinująca pojęcie niezależności to nieskazitelność charakteru, czyli całokształt cech indywidualnych, zdarzeń i okoliczności składających się na wizerunek osoby zaufania publicznego. Termin „nieskazitelny charakter”, używane tak często przez ustawodawcę, jest nieostry, niezdefiniowany, to zwrot niedookreślony odwołujący się do przesłanek uznaniowych, o charakterze ocennym. Ustawodawca stosuje ów zwrot, gdy zamierza obdarzyć organ podejmujący decyzję pewną swobodą, elastycznością pozwalającą zastosować normę zawierającą zwrot „niedookreślony” w najróżniejszych sytuacjach, niemożliwych do wymienienia w przepisie, a nawet do przewidzenia ${ }^{14}$. Naczelny Sąd Administracyj-

13 T. Scheffler, O godności zawodu radcy prawnego, „Radca Prawny” 181, 2019, s. 47.

14 Por. M. Zieliński, Wykładnia prawa. Zasady. Reguły. Wskazówki, Warszawa 2002, s. 170. 
ny wskazał między innymi, że przez nieskazitelność charakteru należy rozumieć takie cechy charakteru, jak szlachetność, prawość, uczciwość. Są to zatem cechy wartościujące konkretną osobę nie w sferze intelektualnej i profesjonalnej, lecz wyłącznie etyczno-moralnej. Nieskazitelność charakteru oznacza pełną wiarygodność i odpowiedzialność, całkowite zaufanie i nieistnienie jakichkolwiek okoliczności negatywnych podważających ową cechę nieskazitelnego charakteru ${ }^{15}$.

Cechy składające się na „nieskazitelność charakteru” wartościują konkretną osobę nie w sferze intelektualnej i profesjonalnej, lecz wyłącznie etyczno-moralnej ${ }^{16}$. Organy korporacyjne nie mogą traktować konieczności badania przedmiotowej przesłanki jako podstawy do sprawdzania umiejętności w zakresie udzielania pomocy prawnej ${ }^{17}$. Oczekiwanie jakiejś pełni „nieskazitelnego charakteru” to utopia, gdyż „od ideałów, jak od gwiazd, dzielą nas całe światy...”18.

\subsection{ODWAGA W WYKONYWANIU CZYNNOŚCI ZAWODOWYCH}

W końcu ostatnią przesłanką niezależności jest odwaga - autor niniejszego opracowania przez „odwagę (radcy prawnego)” rozumie przede wszystkim nieuleganie wpływom osób trzecich w trakcie udzielania pomocy prawnej, stosowanie prawa $\mathrm{w}$ zgodzie z zasadami jego wykładni. Aby klienci i społeczeństwo mogli polegać na rzetelności i wiedzy radców prawnych, radcowie muszą być niezależnymi od państwa, niezależnymi od swoich klientów — nie powinni ulegać instrukcjom stron trzecich, szanować poufność, przestrzegać zakazu reprezentowania sprzecznych interesów, wykonywać szczególne obowiązki w zakresie należytej staranności w odniesieniu do powierzonych im spraw.

$\mathrm{Z}$ działalnością radcy prawnego ten atrybut niezależności wiąże się z niepodleganiem zewnętrznym naciskom w związku ze świadczeniem pomocy prawnej. Niezależność oznacza w tym przypadku obiektywne korzystanie przez radcę prawnego z własnej wiedzy i doświadczenia niepowiązanych w żaden sposób zależnością od klienta lub jakichkolwiek innych czynników zewnętrznych. Niezależność to samodzielne podejmowanie decyzji, niepodyktowane naciskami $\mathrm{w}$ trakcie trwania jakiegokolwiek postępowania.

Podobne uwagi należy poczynić zresztą w kontekście świadczenia pomocy prawnej podmiotom władzy publicznej oraz publicznym podmiotom gospodarczym. Profesjonalny pełnomocnik powinien dbać o interes klienta, pamiętając przy tym o realizacji interesu publicznego.

15 Por. wyrok NSA z 15 kwietnia 2011 roku, II GSK 458/10, Legalis.

16 Zob. także wyrok NSA z 21 czerwca 2007 roku, II GSK 55/07, Legalis.

17 Podobnie P. Kaczmarek, O rękojmi prawidłowego wykonywania zawodu adwokata oraz radcy prawnego, „Przegląd Prawa Publicznego” 2015, nr 1, s. 20.

18 M. Laskowski, Ustawowe pojęcie „nieskazitelność charakteru”, „Prokuratura i Prawo” 2008, nr 6, s. 62. 


\section{ZAKOŃCZENIE}

Zawód radcy prawnego powinien być — zwłaszcza dzisiaj - misją. Radcy prawni mają obowiązek dbać o realizację bezpieczeństwa prawnego obywateli, przedsiębiorców i innych, tych, którzy powierzają im swoje sprawy, interesy, tajemnice. Ważnym elementem wypełniania ich misji staje się ochrona tajemnicy zawodowej. Pełnią oni ważną funkcję publiczną, mimo że ich działalność nastawiona jest oczywiście również na osiągnięcie środków pieniężnych służących utrzymaniu. Ciąży na nich szczególna odpowiedzialność za ochronę praw i wolności obywatelskich. Realizowanie wskazanych przesłanek pomoże zachować niezależność.

Aby społeczeństwo mogło polegać na rzetelności i wiedzy radców prawnych, muszą oni pozostawać niezależni od państwa, nie powinni ulegać instrukcjom stron trzecich, szanować poufność, która jest podstawowym elementem wykonywanego zawodu zaufania publicznego, przestrzegać zakazu reprezentowania sprzecznych interesów, wypełniać szczególne obowiązki w zakresie należytej staranności w odniesieniu do powierzonych im spraw, gwarantować wszystkim dostęp do wymiaru sprawiedliwości w kontekście poradnictwa, pomocy prawnej i obowiązkowej obrony, a także posiadać stale poszerzaną wiedzę specjalistyczną. Kompleksowa, stała i jednoczesna realizacja wszystkich tych elementów jest niemożliwa w dłuższym czasie dla pojedynczego radcy prawnego.

\section{ON THE ESSENCE OF THE PROFESSION OF ATTORNEY-AT-LAW}

Summary

The subject of the article are considerations devoted to the special features a professional legal representative should possess. The existence of the profession of attorney-at-law as a profession of public trust and ethical ideals and obligations formed in the course of its exercise are one of the guarantees that the principle of the democratic rule of law contained in the Constitution of the Republic of Poland will be implemented. Attorneys-at-law participate in the process of deciding on the implementation of the public interest and securing the subjective rights of citizens, entrepreneurs, and other organizational units. Therefore, the essence of the functioning of these self-governments is acting for the common good in the scope in which it can support and, above all, supplement the performance of tasks by public authorities. Every attorney-at-law should be independent. Professionalism, dignity in performing the profession, impeccable character, and courage in performing professional activities become the determinants of independence.

Keywords: attorney-at-law, profession of public trust, professionalism, dignity 


\section{BIBLIOGRAFIA}

Czeszejko-Sochacki Z., Prawo do sądu w świetle Konstytucji Rzeczypospolitej Polskiej (ogólna charakterystyka), „Państwo i Prawo” 1997, nr 11-12.

Kaczmarek P., O rękojmi prawidłowego wykonywania zawodu adwokata oraz radcy prawnego, „Przegląd Prawa Publicznego” 2015, nr 1.

Kłopocka M., Prawo do sądu w orzecznictwie Trybunału Konstytucyjnego, „Przegląd Prawa i Administracji” 76, 2008.

Sarnecki P., Komentarz do art. 17 konstytucji, [w:] Konstytucja Rzeczypospolitej Polskiej. Komentarz, t. 4, red. L. Garlicki, Warszawa 1999-2007.

Sarnecki P., Opinia w sprawie wyktadni art. 17 ust. 1 Konstytucji Rzeczypospolitej Polskiej, „Przegląd Sejmowy" 2001, nr 2.

Sarnecki P., Pojęcie zawodu zaufania publicznego (art. 17 ust. 1 Konstytucji na przykładzie adwokatury), [w:] Konstytucja. Wybory. Parlament. Studia ofiarowane Zdzisławowi Jaroszowi, red. L. Garlicki, Warszawa 2000.

Sarnecki P., Radca prawny jako zawód zaufania publicznego, „Radca Prawny” 2002, nr 4-5.

Scheffler T., O godności zawodu radcy prawnego, „Radca Prawny” 181, 2019.

Soltys B., Komentarz do art. 2, [w:] Ustawa o radcach prawnych. Komentarz, red. T. Scheffler, Warszawa 2018.

Tabernacka M., Pojęcie zawodu zaufania publicznego, „Przegląd Prawa i Administracji” 62, 2004.

Wróbel A., Prawo do sądu, [w:] Konstytucja RP w praktyce. Konferencja naukowa, Warszawa 1999.

Wróbel A., Prawo do sądu w orzecznictwie Trybunału Konstytucyjnego, „Przegląd Prawa i Administracji” 2008, nr 76.

Zieliński M., Wykładnia prawa. Zasady. Reguły. Wskazówki, Warszawa 2002. 